\title{
Anomalies in Family Planning in Central Java, Indonesia
}

Komunitas: International Journal of Indonesian Society and Culture 10(1) (2018): 86-91

DOI:10.15294/komunitas.v9i1.9634

(C) 2018 Semarang State University, Indonesia p-ISSN 2086 - 5465 | e-ISSN 2460-7320 http://journal.unnes.ac.id/nju/index.php/komunitas

UNNDS JOURNALS

\section{Saratri Wilonoyudho', Sucihatiningsih Dian Wisika Prajanti ${ }^{2}$}

1,2Universitas Negeri Semarang, Indonesia

Received: 4 April 2018; Accepted: 18 December 2018; Published: 30 March 2018

\begin{abstract}
This study was aimed at uncovering the anomalies in the implementation of the Population, Family Planning and Family Development Program in Central Java province. Qualitative-naturalistic approach was employed. The results of the study about the population and family planning in Central Java Province is showed an alarming rate of TFR (Total Fertility Rate) indicator of 2.3 to 2.5. In addition, the public mind set about the ideal number of children in a family also increased from the TFR indicator of 2.6 to 2.8. This mindset would hinder family planning program. To overcome the anomalies, BKKBN Central Java Province made various strategic efforts. The high rate of CPR (Contraseptive Prevalence Rate) which was not followed by the low rate of TFR was assumed to be related to the active family planning participants were not using long term contraception method, leaving them vulnerable to drop out. Therefore, an increase in long term contraception method, would be a top priority in the population and family planning program in Central Java. In the "anomaly" of having high CPR numbers but low TFR, operational strategy required to be conducted was to increase the Educational, Information, Communication (EIC) Program, especially for the younger generation, because young age marriage was prevalent in those areas.
\end{abstract}

\section{Keywords}

anomaly; population; family planning and family development program; program management; strategic solutions

\section{INTRODUCTION}

The background of this study is a phenomenon in Central Java Province showing how varied the problems and achievement and the results of family planning programs in the regency / city were. According to BKKBN-Badan Kependudukan dan Keluarga Berencana Nasional/National Board of Population and Family Planning Central Java Province in 2015 there were "anomalies" or deviations from one regency / city to another. In regencies grouped in quadrant I there were pretty "strange" anomalies, in which the number of Total Fertility Rate (TFR) was very high, while they achieved the high
Contraceptive Prevalence Rate (CPR). An example is Wonosobo Regency which has CPR $71.8 \%$ (high) and TFR 3.0 (high). Some regencies/cities which belonged to quadrant II showed low CPR, but high TFR. Quadrant III had low CPR, but the low TFR, Pekalongan City with CPR $50.8 \%$ (low) and TFR 2.0 (low). Quadrant IV had high CPR and low TFR.

One important indicator in population and family planning program is the decli-

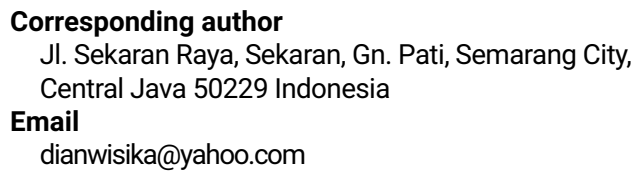


ning birthrate and is commonly measured by the Total Fertility Rate (TFR). The decline in TFR has become an important indicator. The control quantity of the population would be considered successful if the there is a decline of TFR.

Five-year data issued by BPS-Statistics Indonesia $(2004,2008,2013)$ showed that the rate of TFR in Central Java Province has increased 2.1 in 2003, and then rose to 2.3 in 2007 and increased to 2.5 in 2012 respectively. If the TFR was 2.5, then the Central Java Province would have faced problems because of high population density. The population of Central Java was 32,382,657 in 2010, with density of 995 people per $/ \mathrm{km}^{2}$. Approximately 14 percent of the Indonesian population inhabited Central Java (BPS-Statistics Indonesia, 2011).

The increasing use of contraceptives should be used as one of the tools to reduce the number of TFR. The use of contraceptives is usually measured by the percentage of Contraceptive Prevalence Rate (CPR), which is the percentage of active family planning coverage than the amount of reproductive age couples in a certain area at a certain time. The percentage of women of reproductive age using (or whose partner is using) a contraceptive method at a particular time (BKKBN only counts modern methods).

\section{LITERATURE REVIEW}

According to the theory, the population growth can be reduced if fertility can be controlled and unwanted fertility can be reduced. The survey data from 40 developing countries showed that $21 \%$ of births fertility was not wanted (Bongaarts, W Parker Mauldin, and James F Phillips, 1990). The anomaly of family planning program can also be sourced from recording errors. According to Nortman and G. Lewis (1984), statistics showed that there were many significant mismatches between the high proportions of couples who declared not wanting to have more children on one hand. On the other hand, the low proportion of their contraceptive practice.
Bruce (1990) suggests an increase in the quality of service, with six of the following elements, namely: choice of contraception method, information given to users, skill personnel, relationships between the client - the officer, the mechanism of repeated contact and continuity, accuracy constellation of the service. Hermalin and Entwisle (1985) also corroborate that a service management consisting of six components. Those six components cover the scope of services provided by on-site service, particularly for the specific contraception methods, and the quality of service, which includes the elements such as the waiting period, training and skills of staff, privacy and decency by the client, and the length of operation.

Basu (2007) in India finds that the measured success of family planning policy in the developing world rests on increases in the 'modern' methods of contraception. By extension, 'traditional' methods of contraception are equated with traditional mentalities and insufficient motivation to control fertility. In other side, Adioetomo (1993) examines socio-economic characteristics of women and contraceptive use can be seen as individual factors that influence their statement of Ideal Family Size, but factors such as a bureaucratic commitment to reducing fertility and the cultural milieu also play an important role in Javanese women's formulation of Ideal Family Size.

Luo and Zhuoyan Mao (2014) showed that attitudes towards fertility, subjective norms, and perceived behaviour control all contribute significantly to the discrepancy between fertility intention and behaviour. The result shows that, given the situation of being qualified to have two children according to the government's birth control policy, when faced with the choice of whether to have a second child or not, people tend to make their decisions rationally. In addition, the formation of a concrete birth plan is a major driving force for fertility translating intention into action.

\section{RESEARCH METHODS}

This study was aimed at analysing the factors that contribute to the making family 
planning anomaly in Central Java Province, as well as to provide strategic solutions to address these problems. This study employed an integrated approach of qualitative and quantitative, such as the results of survey and BPS-Statistics Indonesia, BKKBN data. Researchers also used focus group discussions and in-depth interviews. The site of the study was located in Wonosobo Regency and Pekalongan City in Central Java Province of Indonesia.

\section{ANOMALY IN WONOSOBO}

The results of the study in Wonosobo Regency, Central Java Province, showed a unique thing which was the high CPR with high TFR. The high TFR in Central Java was an aggregate of a number of TFR in the regency/city, and some problem could be identified from these following sources:

First, the regency does not have sufficient human resources, both quality and quantity, as demographers, population statisticians, health workers, special clinic for family planning.The results of the interviews and observations in the field (in Wonosobo Regency) revealed that the number of family planning officers was reduced to only 72 people to serve 265 villages, and they currently serves 8 ,ooo households. It certainly made it difficult to serve each of them excellently, especially those experiencing problems using contraception.

Family planning program in Wonosobo Regency that Education, Information and Communication (EIC) Program were carried out incidentally and also "integrated" other activities at the event at the village level / districts / countries like community activities. When EIC was implemented, brochures were distributed on family planning to be read by people individually. The only problem was the low budget to make the brochure which was only Rp.20 million (1,200 US dollars) per year.

Second, the reproduction behaviour in Wonosobo Regency was influenced by several factors, including the difficulty in accessing qualified service of family planning program. In addition to the limited use of contraceptives especially in rural areas, the highest poverty rate in Central Java Province $(22.2 \%)$ and the low average length of time spent in school at 6.56 years. Consequently, only 58 percent of family planning was, which is paid at a private clinic (BPS-Statistics Indonesia, 2015); In other side, the absence of local communities to run the family planning program, and the early marriage age (women under 19 years, and men under 21 years old) was still prevalent. Base on BKKBN (2015), in Wonosobo Regency, the first married age (mean : 19, 4 years old; median : 19 years old), the first age of pregnancy (mean : 20,3 years old; median : 20 years old), and the first age childbirth (mean : 21 years old; median : 21 years old).

However until now, what happened was it did not count for a couple who was considered not in need of contraception at the time of the study, even though they prevent or delay births in the future according to Westoff and Pebley (in Nortman D. and G. Lewis, 1984). Identifying pregnant women accurately was also a challenging task to do especially on the early stage of pregnancy, and there is an abortion caused by urgent condition. Therefore, it could be that pregnant more than is recorded (when given contraceptives). For women who breastfeed are also not be free from the risk of pregnancy (McCann 1981).

\section{CASE STUDIES IN PE- KALONGAN}

The results of the study in Pekalongan City Central Java Province showed a unique thing which was the low CPR with low TFR. From the study, the phenomenon was caused by the voluntary abstinence. Davis and Blake (1956) corroborated that the voluntary abstinence among the variables contributes to the reduction in fertility. The theory of decline in fertility by Jain (1989) argues that that the continuity and effectiveness of a method must be approved by the public before it can lower the TFR. The second cause of Pekalongan City case was the migration behavior. The results of interviews with couples who did not use modern contraception revealed that they practiced family 
planning through the voluntary abstinence. Her husband migrated outside the city and only return once in three months.

BPS-Statistics Indonesia (2011) data showed that the number of people who are risen migrants in Central Java continued to increase over time. The results of data showed that 5, 396, 419 people or 2.5 percent of the population was an inter-provincial risen migrants. These facts showed that fertility decline may be associated with changes in the economic behaviour of childbearing age couples. Spoorenberg (2009) adds that in Mongolia, as a consequence of the transition to democracy and a market economy, Mongolia experienced an impressive fertility reduction. In the same cases, Shavazi and Peter McDonald (2006) corroborates that by a socio-political history of Iran in the years 1970-2000, conclude with some speculations linking specific socio-economic and political changes to the demographic change (continued low fertility) in Iran.

BKKBN (2015) data that in 2013, 73.9\% citizens in Pekalongan City carried out independent family planning at their own expense through private clinics, and only $12.5 \%$ joined free family planning program from government clinics. Only unfortunately only $13 \%$ of them used long term contraception method, while the rest used nonlong term contraception method which are prone of dropping out. Therefore, it is suggested that people are willing to switch to long term contraception method.

The results of this study also showed that independence in family planning in Pekalongan City can be caused by the number of poor people in this city which was "only" 9.47\%. Moreover, most of Pekalongan City citizens work in the industrial sector and the percentage of women working was about $42.12 \%$. This figure is quite large. As a consequence, it affects the bustle of a mother and is also expected to affect the perception of the number of children they have.

The low TFR in Pekalongan City was also associated with high political commitment of family planning program development. The results of focus group discussions revealed that the Mayor of Pekalongan City and Regional Parliament member strongly supported this program. Regional Regulation on the Acceleration of the Family Welfare Development and Regional Regulation on Rural Area Institution were issued to support the family planning program. The family planning program also received a prominent place by the empowering of Educational Information Communication (IEC) by giving money in the amount of Rp. 500. 0oo (50 .oo US \$) for anyone who had vasectomy. The results of the study in Thailand was corroborated by Kalwij (2016) arguing that the institutional approach to empower local communities becomes the main factor.

Those couples who have just used contraceptives receive transport money in the amount of Rp 50. 000, oo (3.00 US \$) and groceries. The Rural Area Institution was the institution to decentralize authority. There were about 80 activities were transferred to the Rural Area Institution, because the community was considered able to run those activities.

The role of the government is important, because the results showed that consumption of food and nutrition is almost close to the recommended nutrition adequacy standard. The variables of household head age, family size and income are positively and significantly correlated to energy and protein consumption adequacy of the family, while the factor of household head education was unrelated (Suandi and Damayanti, 2016). This demographic investment was a form of creativity from the local government to "work" on potential family planning clients. Freedman (1975) argues that to reduce fertility, intermediate variables that have been given by Davis and Blake (1956) must be expanded and be preceded by serious study. On the other hand, Lapham and Mauldin (1972) suggest political commitment and adequate budgetary allocations. In addition to a vigorous campaign through mass media.

\section{CONCLUSION}

From the results of the study and the UNNDS JOURNILL 
mapping, it can be concluded that:

1. Population and family planning issues in Central Java Province do not only include technical issues, but also originate from the public mindset about the ideal number of children which rose from 2.6 children to 2.8 children;

2. The high CPR with the low rate of TFR was presumably caused by inaccurate data collection to the unrepresentative population. This problem was caused by the untrained data collectors, or because of psychological pressure to achieve the target of new participants which resulted in less accountability;

3. Another cause was the weak commitment of the policy leading to the limited supply of contraception and the declining number of family planning program member. The family planning program receivedless support from the stakeholders such as the media, political parties, interest groups, and etc. The weak population strategy as a result of the weak link between bureaucratic and political system which issued the population program and the action.Therefore, it did not form the norms of reproduction, and then to intermediate variables and to the decline in TFR.

\section{SUGGESTIONS}

From the conclusion above, the suggestions can be formulated as follows:

1. To overcome the low TFR with the low CPR, improving human resources quality should be carried out to be able conduct research and simulations to produce: a needs analysis of contraception, analysis of unmet need (measurement of unmet needs), because in the status quo, the unmet needs was only for legally married.

2. The high number of TFR must be followed by public policy (population policy) which is designed seriously and systematically to influence the TFR as: demographic behaviour, human resources, and patterns of staff, style of leadership, logistics, and training. The aim of population policy was to increase public demands. If demand increases, then even without any family planning program, the community has carried out their own family planning program. In other words, the increase in supply (supply) will affect the demand (demand).

\section{REFERENCES}

Adioetomo, S.M., 1993. "Construction of Small-Family Norm in Java". Unpublished Ph.D thesis. Australian National University, Canberra Australia.

Basu, M.A., 2007. "Ultramodern Contraception : Social Class and Family Planning in India”. Asian Population Studies, 1, pp. 303-323

BPS-Statistics Indonesia.2004.Demographic and Health Survey 2003

BPS-Statistics Indonesia. 2008.Demographic and Health Survey 2007

BPS-Statistics Indonesia. 2011. Population Census 2010

BPS-Statistics Indonesia. 2013.Demographic and Health Survey 2012

BPS-Statistics Indonesia. 2015.Central Java Province in Figures 2014.

BKKBN (Badan Kependudukan dan Keluarga Berencana Nasional/National Board of Population and Family Planning Central Java Province). 2015. Family Data Collection in 2014

Bongaarts, J., W. P. Mauldin, and James F. P. 1990. "The Demographic Impact of Family Planning Programs". Studies in Familiy Planning, 21 (6), pp 299-310.

Bruce, J., 1990. "Fundamental Elements of the Quality of Care : A Simple

Framework." Studies in Family Planning, 21. (2), pp. $61-91$.

Davis, K. And J. Blake., 1956. "Social Struture and Fertility : An Analytic Framework", Economic Development and Cultural Change, 4, pp, 211-235.

Freedman, R. 1975. The Sociology Human Fertility. Irvington Publishers Inc.

Hermalin, A. I. and Barbara E., 1985. "Future Directions in Analysis of Contraceptive Availability." in International Population Conference, Florence, 3, pp. 445-456. Jain, A.K., 1989. "Fertility Reduction and the Quality of Family Planning Service". Studies in Family Planning, 20 (1), pp 1-16.

Kalwij, A., 2016. "The Effects of Setting Up a National Family Planning Program in Local Communities on Women's Contraceptive Experiences and Fertility in Rural Thailand". Asian Population Studies, 12, pp. 156-176.

Lapham R.J. and Mauldin, W P.,1972. "National Family 
Planning Programs : Review and Evaluation". Studies in Family Planning, 3 (3), Pp. 29-52.

Luo, $\mathrm{H}$ and Zhuoyan M., 2014. "From Fertility Intention to Fertility Behaviour : An Empirical Study in China's Jiangsu Province Based on The Theory of Planned Behaviour". Asian Population Studies, 10, pp. 195-207.

McCann, M. F., and Others., 1981. "Breastfeeding, Fertility and Family Planning". Population Reports, Series J. No. 24.

Nortman D. and G Lewis., 1984. “ A Time Model to Measure Contraceptive Demand". Survey Analysis for the Guidance of Family Planning Programs. J Ross and McNamara (eds). Ordina
Editions. pp. 37-47, Liege Belgium:

Shavazi, M. J. A. and Peter McD., 2006. "Fertility Decline in The Islamic Republic of Iran 1971-20oo. Asian Population Studies, 2, pp. 217-237.

Spoorenberg, T., 2009. "The Impact of The Political and Economic Transition on Fertility and Family Formation in Mongolia : A Synthetic Parity Progression Ratios Analysis". Asian Population Studies, 5, pp. 127-151.

Suandi, S and Yusma D., 2016. "The Relationship between Socioeconomic Status and the Patterns of Food and Nutrition Consumption of the Household in Rural Areas of Muaro Jambi Regency”. Komunitas, 8 (1) pp. 118-124. 